\title{
Interstrand Cross-linking of DNA by FK-317 and Its Deacetylated Metabolites FR70496 and FR157471 ${ }^{\dagger}$
}

Robert M. Williams* and Pascal Ducept

Department of Chemistry, Colorado State University, Fort Collins, CO 80523, USA

\section{Supporting Information}

Synthesis of FR70496 (5):

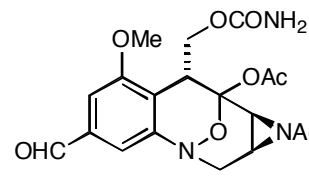

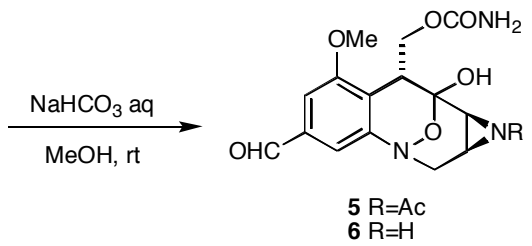

To a solution of FK317 (4) $(0.021 \mathrm{~g} ; 0.05 \mathrm{mmol})$ in methanol $(1 \mathrm{ml})$ was added $\mathrm{NaHCO}_{3}(0.006 \mathrm{~g}$; $0.075 \mathrm{mmol})$. The mixture was stirred at $\mathrm{rt}$ and monitored by TLC (20:1 DCM:MeOH). After consumption of the starting material, the reaction was quenched by the addition of sat. aq. $\mathrm{NH}_{4} \mathrm{Cl}(3$ $\mathrm{ml})$. The aqueous layer was extracted with ethyl acetate $(3 \times 5 \mathrm{ml})$ and the combined organics dried $\left(\mathrm{MgSO}_{4}\right)$, filtered and evaporated under reduced pressure. The crude product was purified by PTLC (25:1 DCM:MeOH) to yield FR70496 (5) as a white solid (0.013 g, 68 \%).

${ }^{1} \mathrm{H}$ NMR (300 MHz, CDCl $)$ ): $1.85(3 \mathrm{H}, \mathrm{s}), 2.77(1 \mathrm{H}, \mathrm{dd}, \mathrm{J}=6.5 \mathrm{~Hz}, \mathrm{~J}=2 \mathrm{~Hz}), 3.17(1 \mathrm{H}, \mathrm{d}, \mathrm{J}=6.5$ Hz), $3.23(1 \mathrm{H}, \mathrm{d}, \mathrm{J}=3 \mathrm{~Hz}), 3.67(2 \mathrm{H}$, appar t, J = $9 \mathrm{~Hz}), 3.88(1 \mathrm{H}, \mathrm{d}, \mathrm{J}=2 \mathrm{~Hz}), 3.89$ (3 H, s), 4.55 (1 $\mathrm{H}, \mathrm{dd}, \mathrm{J}=12.6 \mathrm{~Hz}, \mathrm{~J}=3.8 \mathrm{~Hz}), 4.77(2 \mathrm{H}, \mathrm{br} \mathrm{s}), 5.05(1 \mathrm{H}, \mathrm{dd}, \mathrm{J}=12.5 \mathrm{~Hz}, \mathrm{~J}=1.3 \mathrm{~Hz}), 6.88(1 \mathrm{H}, \mathrm{d}, \mathrm{J}=$ $1.5 \mathrm{~Hz}), 7.07(1 \mathrm{H}, \mathrm{d}, \mathrm{J}=1.5 \mathrm{~Hz}), 9.86(1 \mathrm{H}, \mathrm{s})$.

Synthesis of FR70496 (6):

FR157471 (6) (0.021 g; $0.05 \mathrm{mmol})$ was prepared as for FR70496 (5) with a reaction time of $24 \mathrm{~h}$. FK317 is rapidly converted to FR70496 which itself is further deacetylated to FR157471 as monitored by TLC (5:5 hexanes:ethyl acetate) to give FR157471 (6) as a white solid (0.0083 g, 49\%).

${ }^{1} \mathrm{H}$ NMR (300 MHz, $\left.\mathrm{D}_{2} \mathrm{O}\right): 3.32(1 \mathrm{H}, \mathrm{d}, \mathrm{J}=5.5 \mathrm{~Hz}), 3.56-3.70(3 \mathrm{H}, \mathrm{m}), 3.74(3 \mathrm{H}, \mathrm{s}), 4.39(1 \mathrm{H}, \mathrm{d}, \mathrm{J}$ $=11.5 \mathrm{~Hz}), 4.98(1 \mathrm{H}, \mathrm{dd}, \mathrm{J}=11.5 \mathrm{~Hz}, \mathrm{~J}=6.0 \mathrm{~Hz}), 7.00(1 \mathrm{H}, \mathrm{s}), 7.07(1 \mathrm{H}, \mathrm{s}), 9.65(1 \mathrm{H}, \mathrm{s})$. 


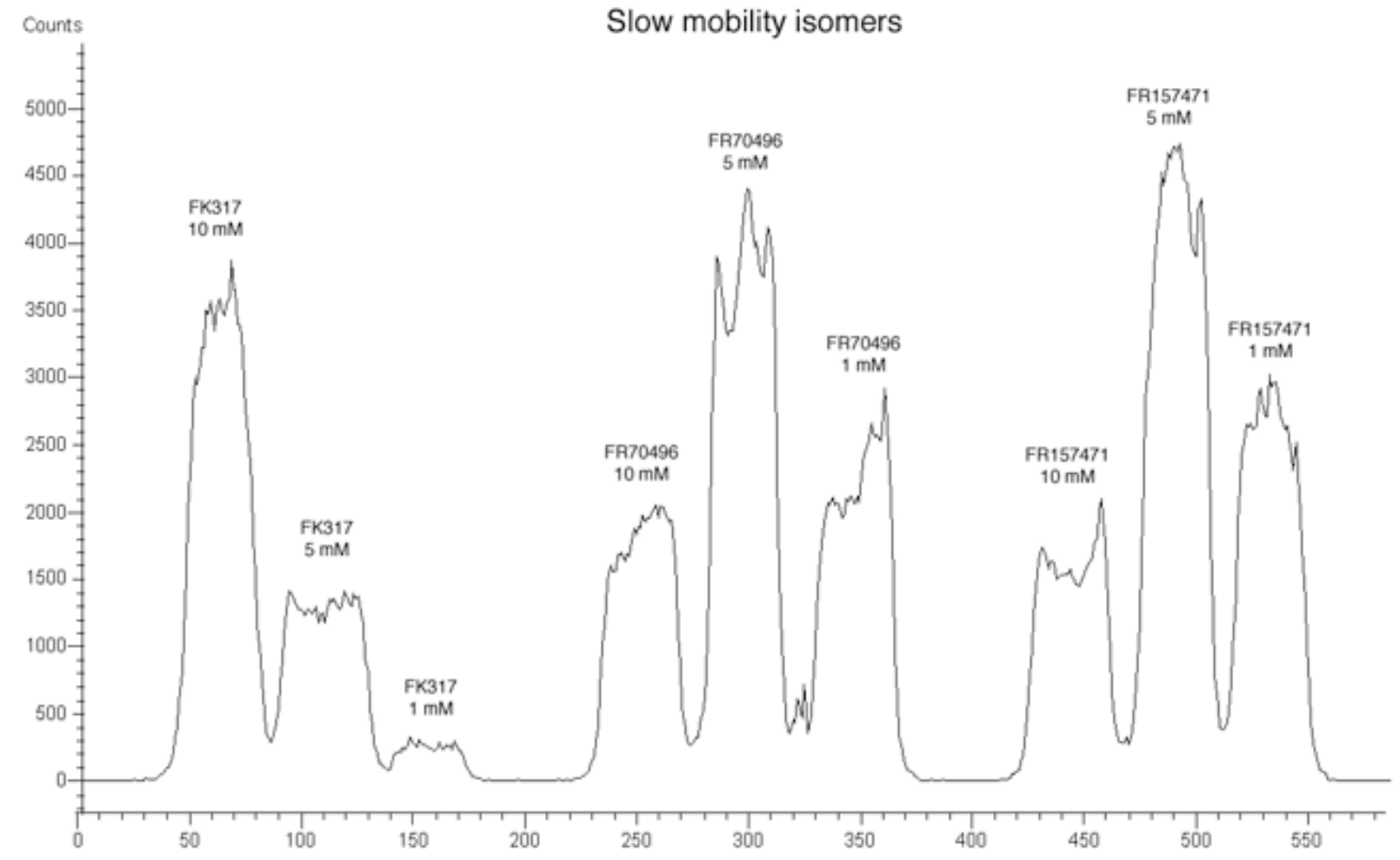

FIGURE 1: Densitometric scan of DPAGE-resolved slow mobility isomers following cross-linking of template A with (4), (5) and (6).

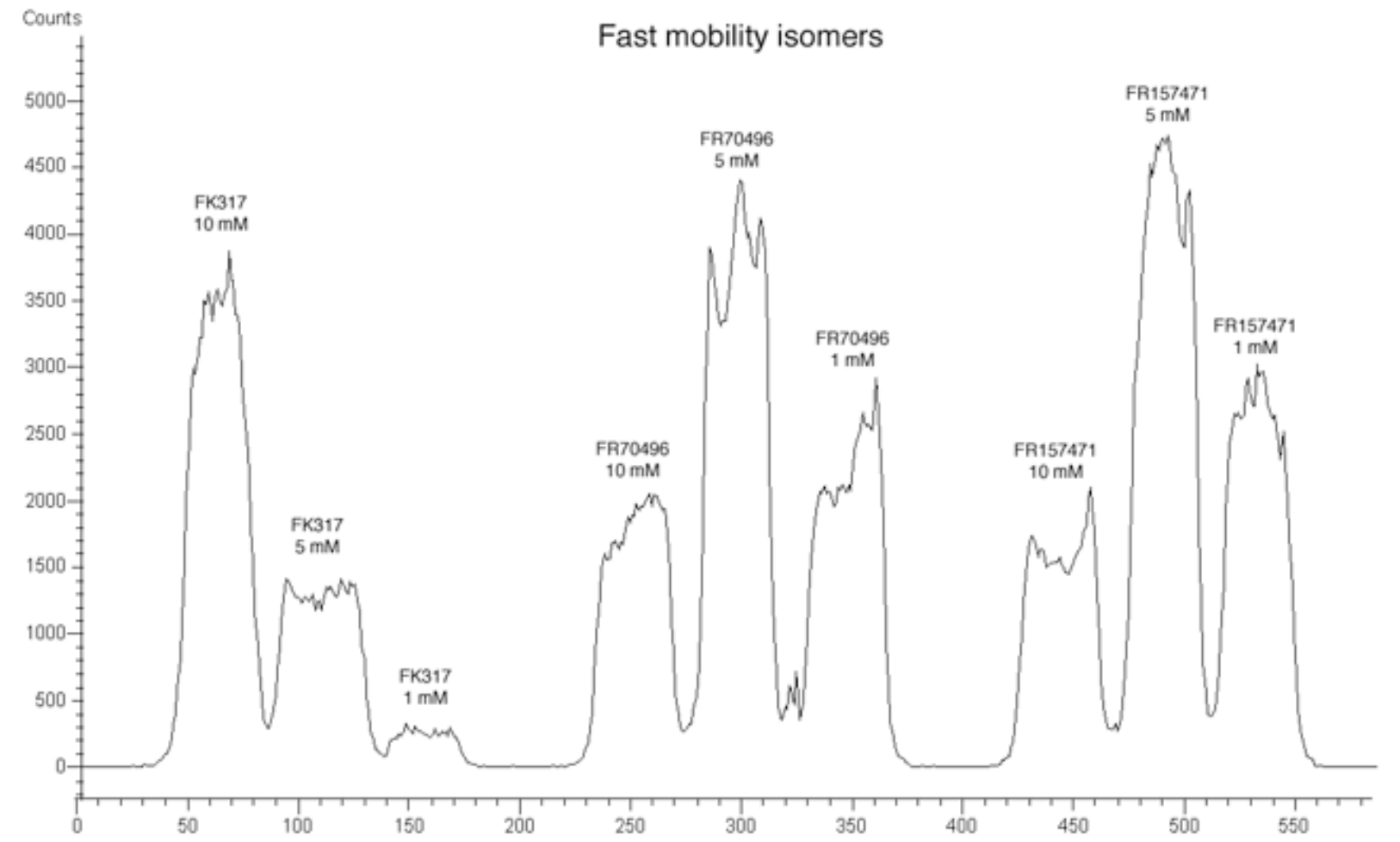

FIGURE 2: Densitometric scan of of DPAGE-resolved fast mobility isomers following cross-linking of template A with (4), (5) and (6). 


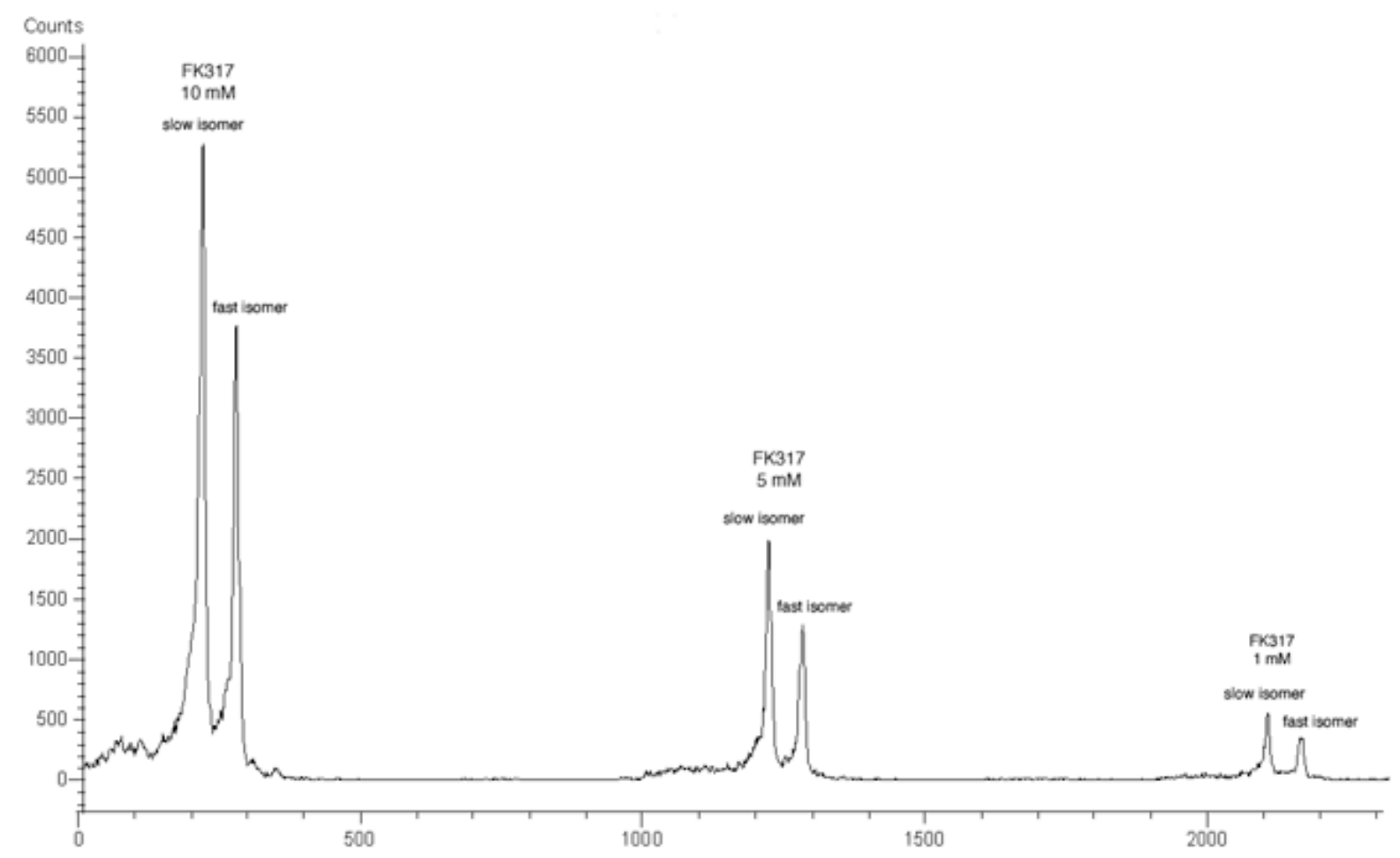

FIGURE 3: Densitometric scan of DPAGE-resolved orientation isomers following cross-linking of template A with (4).

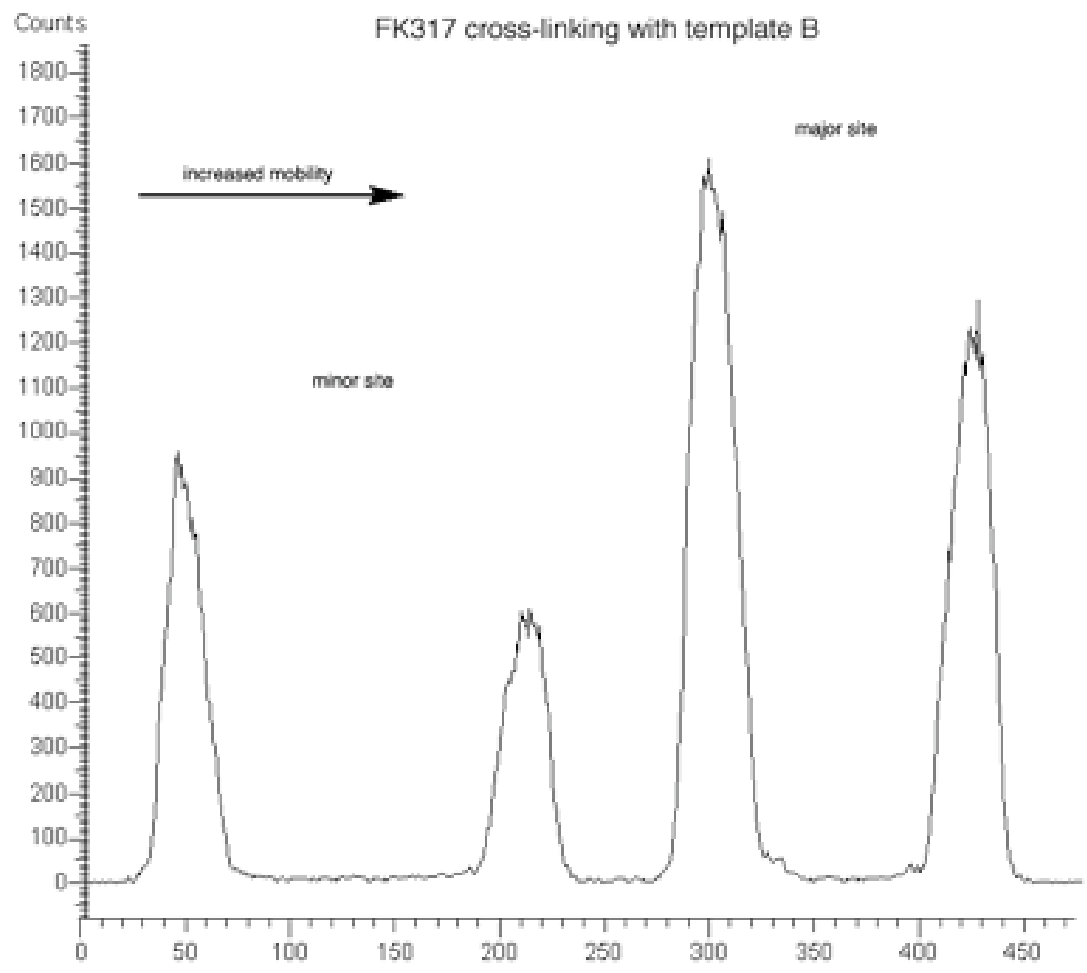

FIGURE 4: Densitometric scan of DPAGE-resolved orientation isomers following cross-linking of template B with (4). 

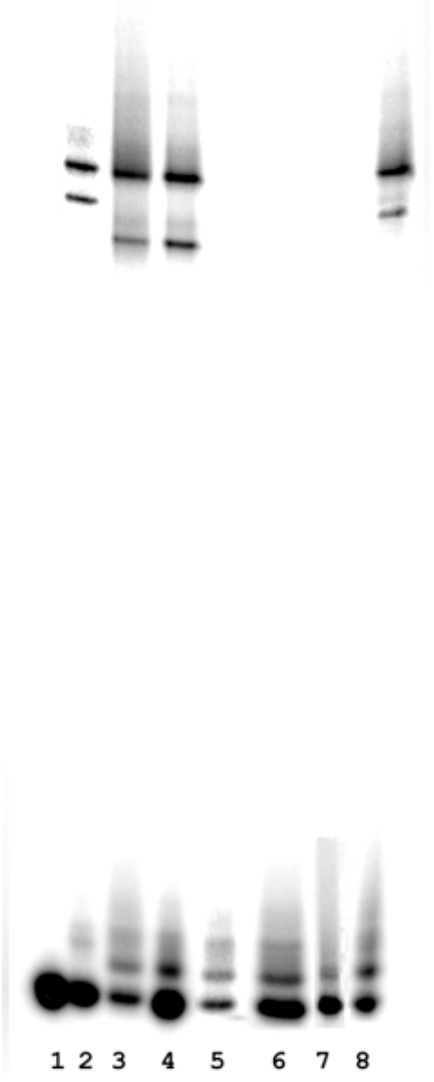

FIGURE 5: Cross-linking of modified template A with (1) and (5). Lane 1: standard DNA, lane 2: DNA + 1 (10 mM), Lanes 3, 4: duplex+10 mM 5, Lane 5, 6: DNA (Inosine modified) $+\mathbf{5}(10$ and $5 \mathrm{mM})$, lanes 7, 8: DNA (7-deazaG modified) $+\mathbf{5}(10$ and $5 \mathrm{mM})$.

Cross-linking assay was carried-out as with native DNA (see experimental part) and all reaction mixtures were analyzed by $20 \%$ DPAGE. 